\title{
Critical Analysis on a Work of Art: Toward Pragmatic Perspective and Supremacy
}

\author{
Patrick Neil M. Santiago \\ Graduate School Student, University of Santo Tomas, Sampaloc, Manila, Philippines \\ Email: patrickneilsantiago1@gmail.com
}

\begin{abstract}
The occurrence of absurdity in art cannot be neglected for there are hidden beauties, purposive and interesting ideas that could be extracted from such kind of absurdity. Some groups are extremely denouncing a work of art. People today begin to confuse that art has become a victim of delusional thought. This paper will investigate the origin of art, its nature, role and purpose and standards of art to affirm the present condition where absurdity occurs. The banishing of art is found unreasonable that exhibits the impossibility of abandonment. The delusional thought of deprived individuals from exercising freedom of artistic impulse is found absurd. The masses then are confined to such dogmatic thoughts that consequently lead individuals to become victims of absurd will. This is the source of severe illness of this present society.
\end{abstract}

Keywords- art, beauty, delusional thoughts, philosophers

\section{BACKGROUND OF THE STUDY}

How should one define the most basic essence of art? How should he understand its complexity and abstraction to achieve the most important message or symbolic meaning of its form? Art is as simple as it is absurd to define. Science may have concrete explanation in every occurrence of matter, but art does not. Many philosophers already attempted to give its meaning but majority of them failed to achieve its entirety to the fullest. Scholars also added that to those who want to attempt to reach and define its pinnacle must forget it. By its nature, art is unfathomable as it gives dynamic representation of human creativity. The more it paints, the larger and deeper it becomes.

In the present condition one severe illness in a community is the banishing of art that sounds extinct on it. Some groups are extremely denouncing a work of art. The masses today begin to confuse others and thereby becoming victims of their delusional thoughts. There is a needful obligation to ponder on these questions: What is art? and How is art denounced by the few?

The issues on art have been remarkably mentioned by most classical philosophers. Philosophers have made an inquiry about the nature of art and responses to its aesthetic beauty. One of the notable critics of art is the famous Greek philosopher Plato (427-347 BCE). For him, art was inferred as an ideal state. What matters is the geniuses of ideas and not the artistic elements of truth and beauty being possessed. In his view in Republic, it is seen that visual art was mimesis. "Mimesis" is a Greek word for imitation and nearest to English word representation [1]. Socrates' examination of the poets had convinced Plato that poets worked as not with conscious intelligence but rather from inspiration [1]. In this inquiry it occurs that truth is not being gained to art to some extent.

To concretize Plato's idea, for instance, an illustration on the concept of a tower that runs into three conditions are as follows: first, condition is the thing-essence of a perfect towerness itself. Second is the actual object-real tower. Considering the Eiffel Tower as an example, the French engineer Gustave Eiffel (1832-1923) built this iron tower, nearly a thousand feet tall. This tower, a million-dollar expensively built emblem of Paris, has become famous all over the world, and no tourist would pass up a visit in Paris without actually seeing it. Thus, the craftsman successfully achieved his purpose of creating a tower. But for Plato, this tower in the real world would lack the perfection of an ideal tower. It reduced the ultimate idea of a thing. In the third condition which is the image. The mimesis then can be attributed to a painter who painted an image of an Eiffel tower. Apparently, the image being made by this painter is then "least truthful" of the three condition and there would be, in the state of ideas, an essence of perfect Eiffel tower. For Plato, beauty is a mode of ultimate ideal-essential properties. The essential ideal-beauty is the core of truth. From this condition, the essential beauty is ultimate and superior to art. This seems to Plato as inciting destructive passion, as its image deviated from the truth [1].

Aristotle (384-322 BCE) opposed the view of his teacher, Plato. Although Aristotle followed his mentor with the basic conception of "art as an imitation of nature", however he refuted some of the principles and ideas of Plato. Aristotle then did not confine mimesis as to be exact context, or as essential replica. He tends to show the 
origin of work of art as to discuss the significance and purpose to humanity. For Aristotle, art can be a window to knowledge. Whereas, Aristotle postulates that men are naturally imitators and learn at first by imitation [2]. He expresses that it is natural for all of us to be delighted by such works of imitation, by seeing the picture, one may learn about the things around him [2]. In the mode of imitation as being natural to man, Aristotle showed that art could be improved on nature, through an artist's original aptitude such as idealization by various means to be used. He believed in the capacity of art to repair the deficiency of nature. In this manner, art could go beyond imitation and accorded to the work of art of some who delved on other artists' mental image. Hence, from the two philosophers' inquiry in regards to the notion of art really occurred the ideas that are complex. For Plato, truth and beauty lies in pure ideas while Aristotle perceives truth and beauty that lies in the form of art.

\section{METHODOLOGY}

This study uses critical analysis on the perspectives and views of the masses regarding art.

According to [3] "a critical analysis is subjective writing because it expresses the writer's opinion or evaluation of a text which was break down and study the parts".

\section{CRITICAL ANALYSIS AND EVALUATION}

\section{A.Art as Dasein}

Dasein is the term that is completely an expression of, not is what, but its being [4]. It is therefore the essential state of Dasein or Being-in-the-world in general. Thus, Heidegger postulates the person is a continuous being who thinks about the meaning of everything not for any result but because he is a thinking being.

A Katana for instance, Samurai's traditional sword in which a weapon composes of wood-leathered handle and sharp iron blade. This weapon cannot be constituted or considered a sword without exercising and utilizing its use and purpose of creation of slashing opponent. The more the man slashing, the more chopping he did, the more action satisfies the idea of a thing-sword is the being-there that made it a Katana itself. The physical substance of an object is not created to one but the spirit of actual involvement between the object and human is the existence of what we called Dasein. This simply means that both the doer and the object become one through their unification; pianist to his piano, painter to his brush and the like.

Bible for example, is considered as a work of art. The work of art is achieved through the unification of the author-God himself, object-the bible and the audienceman. The interconnectedness or fusion of the three elements constitute to what has been assumed as the mechanics of a work of art. If one of the three elements is replaced then it will not complete or satisfy the necessity. For instance, does it make sense whether the bible is written by the Supreme God? Does it matter to everyone its importance? The scriptures said that no one is searching for God, in the same manner no one is eager to read His word. Although one can assume that the author of the bible is transcendental being but one cannot deny the fact that it is still human who translated the word verbatim. Others would testify that it is the exact words of God but it is disciples and His followers who gave personal interpretations of such spoken words. The weight of the words rely heavily on the manner they have been translated and interpreted; hence, perception over conception of the meaning is at stake.

Interpretation cannot capture the exact ideas of humankind and physical world. Logically, it is still the human who serves as the representative or secondary author of the bible. The church for instance, is the anointed authority to preach the word of God. The church then stands as the authority to interpret, arrange and compile the words of God. Bible is the product of church authority. This is why it is assumed that the bible is a work of art due to its man-made intervention though derived from the Spirit of God. The believers known as audience need church as an institution to understand the miracles of God and His teachings. The church is the foundation of teachings that can deeply interpret the thoughts of God. So if one attempts to critically analyze the claim of bible alone, then it will be skeptical and absurd. Why? There is strong probability of misinterpretation of its essence. Assuming that man can stand alone why students should go to school and be taught by his teachers? Why scholars, researchers and academicians undergo higher level of education such as graduate/post graduate studies? It is obvious that those individuals can read, interpret or understand things deeper and very knowledgeable in their chosen fields but they still intend to go higher level of learning and search for deeper meaning and essence. Much depressing to think of an individual who has not been given any small chance to study and be educated. How can he understand the profound teachings of the bible? Considering the multiple misinterpretations that majority can make, the bible alone is impossible to be fully understood. There is clear misinterpretation of its ideas. It is refutable and vague to realize that art itself works alone as some have pronounced. The church, the believers and the bible complement one another. Therefore, the three elements become unified with the utmost intention of creating a craft. The fusion of the three builds a world, the awakening of Dasein. The transformation of the Samurai- 
Kenshin performs into an Art of War, bible-spirit of Jesus into Christianity.

\section{B. Art as Instrumental}

Traditions from both western and eastern practices together with religious rituals and customs, images and statues and the rest of the symbols have received absolute criticisms from the limited perception of the few. They condemned those as pagan traditions that should never be practiced because they are from the work of an evil. According to Jean Paul Getty (1892-1976) as cited by [5], "a philanthropist and art collector who gave a speech about improving the masses. He stated, "Twentiethcentury barbarians cannot be transformed into cultured, civilized human beings until they acquired an appreciation and love for art". Art is part of rich culture and tradition that nourishes human consciousness and sustains development of human civilization. Indeed, the concept of what they assumed evil is the origin of such practices itself that evolved, flourished, influenced, and developed by generations and served as identity of the past civilization. Who can judge them? For instance, the sign of respect for elders which is commonly called "mano" is a practice that must not be despised and replaced as it shows honor and respect for elders. Is it not the other way around that those who do not practice such respect and other customs that originated from the past civilization are the true evil doers? Many avoid the practice of the sign of the cross and reject the representation of Christ in a curved or figurative sculpture nailed on the cross, while other religious groups also have the plain cross and prefer to remain it blank without Jesus Christ's emblem on it. Indeed, the two are both of the same principle. They use representation of the cross. The only thing that makes them different is the qualities or ways of presenting the subject.

The interpretation of things becomes distorted when it is translated into other language or medium of communication. Translation by nature is skeptical and does not absolutely preserve its truest sense and essence from the original meaning and use. The bible for instance was originally written in Aramaic language and has been translated into various thousand of languages and interpretations. It is in this sense to consider with paramount example the utterance of the second commandment, "Thou shall not have other gods before me". This commandment brought endless confusions as it was perceived as a form of idolatry by the Catholic Church. It had gone a lot of debates and disputes about worshipping idols and practicing pagan beliefs. However, Heidegger distinguished the understanding between thing and being. As discussed previously about Dasein, the practice is only a concrete understanding of what can be perceived as a thing. This is to simply put in that the graven image or statue that the Catholics have used is not a violation to the second commandment that God gave to mankind. To some extent, art is not restricted as mimesis or imitation. Art for Aristotle is a resemblance of being. For instance, the image or picture of Jesus Christ is considered as not the real being or person and that this image is just a resemblance of an actual Jesus Christ. So how the picture of Jesus could be considered as a representation of Himself without knowing the actual nor the exact feature of His appearance? Indeed, no one can prove his real appearance, or any persons that personally witnessed His being. Aristotle enumerated three factors of representation namely: a thing, actual thing and mental images. The thing comes from a priori or synthetic object. While the actual thing comes from a posteriori or empirical object, and the mental image is the product of the mind. This mental image is the interpretation of an artist that has been derived from the idea of the object. In connection, the images or pictures of Jesus created by the artist are a mere interpretation or expression aimed to capture the essence of the spirit of Jesus Christ. Hence, the accusation of idolatry is false and considered as void argument to talk about.

Art is really significant in this physical world. One cannot deny the fact that it is part of his daily living. The purpose of art gives significant understanding of one's existence and meaning to life. Adams explains in his book The Methodologies of Art, the theory of image. The imagerycave paintings during pre-historic period were a device as part of wider religious and magical beliefs of the system [6]. Imaging has been remarkably used in medieval period for iconography purposes. However, today visual representation was utilized as amusement through films, virtual games, graphic works and for other purposes. Hence, according to Osborne, one of the approaches to art is "pragmatic" or instrumental. He enumerated art as:
a) Art as manufacture.
b) Art as an instrument of education or improvement.
c) Art as instrument of religious or moral indoctrination.
d) Art as an instrument for the expression or communication of emotion.
e) Art as instrument for the vicarious expansion of experience [7].

Art is derived from the basic interest of an artist. Such interest serves as instrumental purpose to create an art piece. The process of creation of products and objects involves artistic design that is made and processed in the creative thoughts of an artist. This creative design 
employs aesthetical experience such as ceramics that have been imported and exported. Art may also be utilized in education for the purpose of enhancing teaching process that could provide intense learning and understanding, encourage critical thinking activities, analyses and argumentative activities. Art can expound students' thinking capacity. How can student grasp knowledge on slavery, literature, nature and other themes of life without visual aid or visual representation? With art it is more tangible to the mind to imagine things that are unimaginable. While for religious or moral indoctrination, art plays an important role for its attributes, inculcating thoughts or ideas that transfer of culture, custom and tradition from generation to generation through civilization. Likewise, art can be seen as an instrument for the expression or communication of emotion. Moreover, art provides vicarious expansion of experience, extending capacity to perceive and conceive. It is with such virtual imagination by which the actual experience in certain places of the world become closer to senses. For instance, a film through this artform a person can virtually experience. Moreover, adventures and travel to far places can be felt more artistically through arts. Hence, art plays a significant role in almost all fields of life.

The concept of mimetic which is a representation of something or an object must not be misunderstood and judged solely as it is. The term is an attempt to resemble the idea, an interpretation, a memory that one is holding to or a precious moment that one is cherishing. The pragmatic approach to art simply feeds everyone of an understanding that art is thus purposive and significant to human due to his mental incapacity. Scientifically speaking, representations play important instrument that could serve as tools for human in order to conceive ideas and implied knowledge from this physical world. The practice of the sign of the cross for instance, is a symbolic form of language that communicates holiness and honor. The images or statues of representational and figurative cross whether plain or abstract evoke the same language or form, a message of sacrifice and death of Christ.

\section{Art in its Supremacy over Morality}

Intuition is the most vital in art that affords independently and performs in the enigmatic state of art. This occurrence is through purgation from moral or immoral fiber. Through intuitive sphere, art plays supremacy over expression that includes emotion or cognition. How do we say so? In allegorical picture of the notorious assassinthe Samurai-Kenshin tends to overcome the guilt in order to come out the sage that lives in his body that performs into Art of War. In this story it emphasized that the awakening of the said sage is not unto versatile technique of the great master but rather the purgation of the immoral fiber.
The Italian aesthetician, Benedetto Croce (1866-1952) stresses the beauty of art stands independently. Croce emphasizes that any work of art is not logically true, nor economically useful, and not morally good. The idea of Croce is elucidated in the concept of true poetry that must have no utilitarian, moral or philosophical agenda [8]. Art inquiry involves absolute freedom of the artist in dealing with his creations. There is no standard to be considered as the basis for judgment. No one has the right to despise, unless he is the one causing the scorn. This scenario is more evident through the work of Andres Serrano (1950) a well-known contemporary artist through his photos of corpses, his use of feces and bodily fluids in his work became notably famous and controversial with its infamous photography, Piss Christ. Freeland described Piss Christ as a huge photograph that looked monumental and different. The original photograph has qualities that cannot be captured by its reproductions. The artpiece of Serrano's Piss Christ was made using his own urine. The American art critic Lucy R. Lippard (1937) describes Serrano's piece as:

Piss Christ - the object of censorial
furor- is a darkly beautiful
photographic image... The small woo-
and-plastic crucifix becomes virtually
monumental as it floats,
photographically enlarge, in a deep
golden, rosy glow that is both ominous
and glorious. The bubbles wafting
across the surface suggest a nebula. Yet
the work's title, which is crucial to the
enterprise, transforms this easily
digestible cultural icon into a sign of
rebellion or an object of disgust simply
by changing the context in which it is
seen [5].

The composition of Serrano rendered with a disturbing form and content. Serrano used body fluids, religious icon and other foreign objects. This created a shocking feedback as described in the book of Freeland. Without actual seeing, the piece of Serrano as Freeland illustrated has neither provoked nor offended the audience. The characteristic of blasphemous, immorality, sensual or shocking experience is explicitly unacceptable in the context of other's beliefs. Serrano clarified that he did not intend to denounce religion [5], and it is believed that he just wanted to say something and creativity.

Some critics and individuals particularly the religious groups cannot see the beauty behind such works. Their limited thinking capacity relies on the beliefs that are confined and fettered on morality that is concealing within. For instance, the reaction of the critic on 
Serrano's Piss Christ Senator Jesse Helms says, "I don't know Mr. Andres Serrano, and I hope I never met him. Because he is not an artist, he is a jerk" [5]. In contrast, Freeland deeply clarified that art includes not just works of formal beauty to be enjoyed by people with taste or works with beauty and uplifting moral messages, but also includes works that evoke ugly and disturbing portraits with a shattering negative moral content [5]. This means that art has its multifaceted images that project life exactly as it is. Its natural approach to human kind allows the beholder to delve into deeper appreciation of the self, will, desire and the atmosphere in this physical world.

\section{SUMMARY AND CONCLUSION}

The speculative notion in relation to art as imitation of nature has been explicitly clarified by Aristotle who evoked that art is not limited to imitation but rather a representation of nature that is purposive and could serve as the window of knowledge. Thus, the beauty of truth lies in the forms of art.

About the discussion on art as Dasein, it intends to demonstrate the mechanics of a work of art through the essential fusion of the three element wherein the creator, its products and the audience were all involved to interact in the common process. From this viewpoint we can expound the deeper nature of art as to reject the assertion that it can work alone. We see the Bible as the perfect example of art that reveals abstract ideas. The fusion does occur to build a world that shows as the essential stateDasein or Being-in-the-world in general. In religion, the bible is perceived as God's revelation of His mind. God is the author of his thoughts and man is the recipient of this craft. As man interprets God's words he formulates his faith that resulted in the formation of several beliefs such as Christianity. In culture the soul of a finest blacksmith and the versatile swordsman also unify through the object-sword that transforms into cultured Samurai used in the art of war. Art is deemed demonstrated in its spiritual form. Furthermore, we have established the idealistic -essential form of art, consequently, as we extend art into more in-depth appreciation. The critical analysis on the issues and perspectives on art and design is deemed to clarify the irresponsible will of humanity that resulted to misconception about art. Apparently, it is a mere response that demonstrates the significant role of art to the materialistic view. It is now crystal clear that art cannot become obsolete and faded. It has deluded oneself into thinking of rejecting the values brought by rich culture and traditions that had been associated in the human civilization. Moreover, it sounds unreasonable to condemn pagan tradition as evil as this may just accuse the ancestors of the past civilization as enemies.
As we have mentioned above, art is a representation of nature. It signifies purpose in a sensible living. Jetty suggested that the improvement of the masses through acquiring an appreciation and love for art cannot be transformed into cultured and civilized state and will remain barbarians. In addition, Osborne expounded the utilitarianism aspect of art wherein art was seen inevitable and essential in sensible living. Although art is deemed to be spiritual but still it is grounded on a real world, at the same time it is purposive in material world. Art thus plays an important role and purpose as a tool and device in seeing and appreciating life more significantly.

Concerning the standards of art, intuition affords independence that performs in the mode of art. It shows that art occurs as a supreme over expression -emotion or cognition that clearly established the independency over standards of art. Thus, the moral issues that Freeland meant by ugly and disturbing message of art is contrary to the set of moral standards imposed by some institutions today. Their standard is a custom or norm that appears in the subjective taste, judgment and perspective of the many on the essence of true beauty. The negative moral content is not always evil, but it can be transposed to positive purposes. Indeed, there is no rule in art, neither any form nor even standard content. It is absurd to dispute about art in its moral aspect and it does not matter if it is meant to express positive or negative message. Intuition delves the sage that lives in man's body that grasps the very essence of beauty. The beauty of art stands independently. Art concerns both sensual and spiritual beauty. As for Nietzsche, art is not only autonomous but is supreme over morality [8]. Everyone has no fixed standards on art. What one can do is to appreciate the beauty, way of inquiry and expression and contribute to the world of aestheticism and learn from the many endless forms of art where imagination is the only tool that limits the endless expression of beauty and wonders. It can be concluded from the issues raised that art is the fundamental aspect of life. It is deluded into the thinking that banishing of a work of art in practical living. The abandonment of art is found unreasonable. Moreover, this explicitly exhibits the sound impossibility of banishing of art that tends to hinder the humanistic capabilities. The deprivation of exercising freedom on artistic impulse of some religious group appears to be a selfish will. It is regretful to think that the masses are poisoned on this delusional state though it is implied in the minds of many individuals. Nevertheless, the masses are closely confined by these religious thoughts that consequently led individual to become a victim of absurd will which is severe illness of this present world. 


\section{REFERENCES}

[1] Francis MacDonald Cornford, trans. with intro. and notes, The Republic of Plato, New York: Oxford University Press, 1967.

[2] Jonathan Barnes, ed., The Complete Works of Aristotle: Poetics, Princeton, NJ: Princeton University Press, 1984.

[3] Critical Analysis. https://www2.s outheastern.edu/Academics/Faculty/e lejeune/critique.htm).

[4] Martin Heidegger, Being and Time, trans. John Macquarrie and Edward Robinson, Oxford UK: Blackwell Publishers Ltd, 1962.

[5] Cynthia Freeland, Art Theory: A Very Short Introduction, New York: Oxford University Press, 2001.

[6] Laurie Schneider Adams, The Methodologies of Art: An Introduction, USA: Westview Press, 1996.

[7] Harold Osborne, Aesthetic and Art Theory: An Historical Introduction, New York: E. P. Dutton \& Co. Inc., 1970.

[8] Anthony Kenny, A New History of Western Philosophy, vol. 4, Philosophy in the Modern World, New York: Oxford University Press Inc., 2007. 